\title{
O Pensamento Econômico na Idade Média Cristã - Parte $1^{*}$
}

\author{
Murray N. Rothbard
}

\begin{abstract}
Resumo: $\mathrm{O}$ autor relata o pensamento da Igreja na Idade Média, focalizando sua atenção nos aspectos da usura, da cobrança de juros e do "preço justo". Mostra como esse pensamento foi evoluindo ao longo do tempo.

Palavras-chave: História da Economia, Direito, Juros, Usura, Carolíngios, Direito canônico, Decretistas, Decretalistas, Romanistas.
\end{abstract}

\section{The Economic Thought in Christian Middle Ages - Part 1}

\begin{abstract}
The author describes the thinking of the Church in the Middle Ages, focusing their attention on aspects of usury, charging of interest and the "fair price" and shows how this thinking has evolved over time.
\end{abstract}

Keywords: History of Economics, Law, Interest, Usury, Carolingians, Canon Law, Decretists, Decretalists, Romanists.

Classificação JEL: B11, N23

\footnotetext{
* O presente artigo é a primeira metade do segundo capítulo do livro An Austrian Perspective on the History of Economic Thought - Volume I: Economic Thought Before Adam Smith (Ludwig von Mises Institute, 2006).

Traduzido do inglês para o português por Márcia Xavier de Brito.

** Murray N. Rothbard nasceu em 2 de março de 1926, no Bronx, em Nova York. Graduou-se em Matemática, em 1945, na Columbia University, por onde também recebeu, em 1956, o título de Doutor em Economia. Lecionou no Brooklyn Polytechnic Institute, de 1964 a 1986, e na escola de negócios da University of Nevada, em Las Vegas, de 1986 até a morte, em 1995. Rothbard foi o fundador e principal teórico do anarco-capitalismo, um firme defensor do revisionismo histórico, e uma figura central no movimento libertário norte-americano do século XX. É autor de mais de vinte livros, dentre os quais se destacam os tratados de economia Man, Economy, and State: A Treatise on Economic Principles (Ludwig von Mises Institute, 1993) e Governo e Mercado (Instituto Ludwig von Mises Brasil, 2012). Faleceu no dia 7 de janeiro de 1995 em Nova York, nos Estados Unidos.
} 


\section{I - O Direito Romano: Direitos}

\section{De Propriedade e LaISSEZ-FAIRE}

Uma das influências mais fortes no pensamento jurídico, político e nas instituições do Ocidente cristão durante a Idade Média foi o direito romano, proveniente da Roma antiga, da República e do Império. $\mathrm{O}$ direito romano se desenvolveu, classicamente, do primeiro ao terceiro séculos A. D. No direito privado, desenvolveu a teoria do direito absoluto de propriedade privada e a liberdade de comércio e de contrato. Posto que, em teoria, o direito público romano permitisse a interferência estatal na vida do cidadão, havia pouca interferência no final da República e no início do Império. Os direitos de propriedade privada e o laissez-faire foram, portanto, a herança fundamental do direito romano para os séculos posteriores, e muito dele foi adotado por países do Ocidente cristão. Muito embora o Império Romano tenha desmoronado nos séculos IV e V, sua herança jurídica permaneceu incorporada em duas grandes compilações de direito romano: no Ocidente, no influente Código de Teodósio (Codex Theodosianus), promulgado pelo imperador Teodósio II (401-450) em 438 A.D. e, no Oriente, o grande Corpus Juris Civilis (Codex Iustinianus), em quatro volumes, promulgado pelo imperador cristão bizantino Justiniano (483-565) por volta de 530.

As duas coletâneas enfatizavam muito que o preço "justo" (justum pretium) era simplesmente qualquer preço a que tivessem chegado, por negociação livre e voluntária, o comprador e o vendedor. Todo homem tem o direito de fazer o que quiser com sua propriedade, e, portanto, tem o direito de realizar contratos para doar, comprar ou vender tal propriedade. Por isso, qualquer preço livremente acordado é "justo". Assim, no Corpus, vários juristas eminentes do século III citaram o jurista Pompônio, do início do século II, numa expressão clássica da moralidade do laissez-faire: Ao comprar e vender, a lei natural permite que uma parte compre por menos e a outra venda por mais do que a coisa vale; assim, a cada parte é permitido vencer pela astúcia. Diz também que: é naturalmente permitido às partes tirar vantagens, uma da outra, no preço de compra e de venda. O único problema aqui é a expressão estranha, "o que a coisa vale", que admite existir algum valor além da livre negociação a expressar um "valor verdadeiro", uma locução que provará ser arauto infeliz do futuro.

De modo mais específico, o Código de Teodósio é extremamente claro: qualquer preço ajustado por negociação livre e voluntária é justo e legítimo, a única exceção é o contrato realizado por crianças. Força ou fraude, como infrações aos direitos de propriedade eram, por certo, consideradas ilegais. O código afirmava explicitamente que a ignorância do valor de um bem, seja do comprador ou do vendedor, não era base suficiente para a intromissão da autoridade ao rescindir voluntariamente o acordado no contrato. O Código de Teodósio foi transmitido pela Europa Ocidental, por exemplo, no direito visigótico dos séculos VI e VII, e no direito bávaro do início do século VIII. O direito bávaro acrescentou a provisão explícita de que o comprador não podia rescindir uma venda por decidir, posteriormente, que o preço ajustado estava muito alto. Esse aspecto laissez-faire do Código de Teodósio foi incorporado, mais tarde, no direito canônico cristão ao ser incluído na compilação de 'Capitulares' (decretos) por Benedito Levita no século IX'.

Enquanto o corpus justiniano, promulgado no Oriente, era igualmente leal ao laissez-faire, incluía um elemento menor que, posteriormente, cresceu e justificou os ataques à livre negociação. Como parte da discussão justiniana de como as cortes poderiam avaliar a propriedade para o pagamento de danos, o código mencionava que se um vendedor vendesse sua propriedade por menos da metade do "preço justo", então, sofreria uma "grande perda" (laesio enormis), e o vendedor estaria autorizado tanto a receber de volta a diferença

${ }^{1}$ CALASSO, Francesco. Medio Evo del Diritto. Milano: Giuffrè, 1954. v.1, p. 175. (N. do T.) 
entre o preço original e o preço justo do comprador ou receberia de volta a propriedade ao preço original. Essa cláusula, aparentemente, só deveria ser aplicada aos bens imóveis e às compensações por danos, casos em que as autoridades deveriam, de algum modo, calcular o "verdadeiro" preço, e não tendo nenhuma influência nas leis dos séculos seguintes. Produzirá, todavia, efeitos infelizes no futuro.

\section{II - A Postura dos Primeiros Cristãos com Relação aOs Mercadores}

A lei romana não foi a única influência para as ideias econômicas na Idade Média. Posturas ambivalentes na tradição cristã primitiva também provaram ser muito importantes.

As questões econômicas, é claro, raramente eram centrais tanto para o Antigo como para o Novo Testamento e os pronunciamentos econômicos esparsos são contraditórios ou estão sujeitos a interpretação ambivalente. Fulminações ${ }^{2}$ contra o excessivo amor pelo dinheiro não necessariamente encerram uma hostilidade ao comércio ou à riqueza. Um aspecto notável do Antigo Testamento, no entanto, é a repetição, quase pré-calvinista, de exaltar os méritos intrínsecos do trabalho. Em comparação à postura desdenhosa para com o trabalho dos filósofos gregos, o Antigo Testamento está repleto de exortações em seu favor: desde o "Sede fecundos, multiplicai-vos" do Gênesis" até o "Desfruta a vida [...] que Deus te concede debaixo do sol, [...] porque esta é tua porção na vida e no trabalho com que te afadigas debaixo do sol" no Eclesiastes ${ }^{4}$. Estranhamente, essas evocações ao trabalho muitas vezes são acompanhadas por admoestações contra a acumulação de riquezas. Posteriormente, no segundo século a. C., o judeu que escreveu o

\footnotetext{
${ }^{2}$ Sentenças eclesiásticas para que se executem as bulas papais. (N. do T.)

${ }^{3}$ Gn 1,28. (N. do T.)

${ }^{4} \operatorname{Ecl~9,9.~(N.~do~T.)~}$
}

livro apócrifo do Eclesiástico ${ }^{5}$ vai ainda mais além ao exaltar o trabalho como uma vocação sagrada. Os trabalhadores manuais, escreve, "asseguram uma criação eterna, e a sua oração tem por objeto os problemas de sua profissão"6. Buscar ter dinheiro, no entanto, é algo condenado e os mercadores, normalmente, são tratados com profunda desconfiança: "Dificilmente um negociante afasta-se da culpa e o comerciante não está isento do pecado." 7 E mesmo assim, nesse mesmo livro do Eclesiástico o leitor é instruído a não ter vergonha do lucro ou do sucesso nos negócios.

A postura dos primeiros cristãos, e do próprio Jesus e seus apóstolos com relação ao trabalho e ao comércio manifestavam a intensa expectativa do iminente fim do mundo e da vinda do Reino de Deus. Obviamente, se alguém espera o iminente fim do mundo, tal pessoa tende a ter pouca paciência com atividades tais como investir e acumular riquezas; a tendência, ao contrário, é agir como os lírios do campo, para seguir Jesus, e esquecer-se dos assuntos mundanos. É nesse contexto que devemos entender a famosa frase de São Paulo "Porque a raiz de todos os males é o amor ao dinheiro"s.

Aproximadamente no ano 100 A. D., contudo, os livros do Novo Testamento escritos por São João deixam claro que a Igreja abandonou a ideia de fim do mundo iminente. A herança helenística e evangélica, no entanto, fundiram-se e conduziram os primeiros Padres da Igreja a uma vida retirada do mun-

\footnotetext{
5 Também conhecido como Sirácida ou Ben Sirac, este livro é um dos livros denominados "deuterocanônicos", ou seja, livros que só em um segundo momento foram considerados canônicos. O Eclesiástico faz parte da Bíblia grega, mas não figura no cânon judaico (daí o autor chamar de livro apócrifo) e também não é levado em consideração por algumas denominações protestantes. No entanto, a Igreja Católica aceita os livros deuterocanônicos por já constarem na primeira tradução da Bíblia para o latim, feita por São Jerônimo. (N. do T.)

${ }^{6}$ Eclo 38,34. (N. do T.)

${ }^{7}$ Eclo 27,29. (N. do T.)

${ }^{8} 1 \mathrm{Tm} 6,10$. (N. do T.)
} 
do e das atividades econômicas combinadas com as fulminações contra as riquezas e aos mercadores que tendem a acumular tal riqueza. Os Padres da Igreja protestaram contra as atividades mercantis assim como, necessariamente, marcadas pelo o pecado da ganância e, quase sempre, acompanhadas por dolo e fraude. Liderando o cortejo estava o místico e apocalíptico Tertuliano (160-240), um proeminente advogado cartaginês que se converteu tardiamente ao cristianismo e, ao fim, acabou por formar a própria seita herética. Para Tertuliano, o ataque aos mercadores e à geração de dinheiro era parte e parcela de uma invectiva contra o mundo secular, que ele esperava a qualquer momento, afundar em multidões de excedentes populacionais, de modo que em pouco tempo sofreria "epidemias, fomes, guerras, e a terra se abriria engolindo cidades inteiras" como uma solução macabra para o problema da superpopulação.

Dois séculos depois, o inflamado São Jerônimo (340-420), educado em Roma, mas também influenciado pelos padres do Oriente, tomou o tema, proclamando a falácia de que no comércio o ganho de um se baseia na perda de outrem: "todas as riquezas vêm da iniquidade e, a menos que um tenha perdido, outro não pode ganhar. Por isso a opinião comum parece-me ser tão verdadeira, 'o rico é injusto ou é herdeiro de um homem injusto'". E ainda havia outra tensão contraditória, mesmo em São Jerônimo, que também declarou que "um sábio rico possui maior glória que aquele que é somente sábio", pois pode realizar mais coisas boas; "a riqueza não é um obstáculo ao homem rico que a utiliza bem".

É provável que a postura mais inteligente com relação à riqueza e ao ganho entre os primeiros Padres da Igreja tenha sido a do ateniense Clemente de Alexandria (150-215). Ao aconselhar que a propriedade fosse usada para o bem da comunidade, endossou a propriedade privada e a acumulação da riqueza. Atacou a tolice do ideal ascético de se despir das próprias posses. Como Clemente sabiamente expôs, ao empregar um tema de direito natural:
Não devemos jogar fora as riquezas que podem beneficiar ao próximo. As posses são feitas para serem possuídas; os bens são chamados de bens porque fazem o bem, e foram dados por Deus para o bem dos homens. Estão à disposição e servem como matéria, instrumentos para o bom uso nas mãos daqueles que sabem como utilizá-los.

Clemente também teve uma postura intransigente para com os pobres desarraigados. Se viver sem posses fosse tão desejável, ressaltou:

Então, toda a multidão de proletários, desamparados e pedintes que têm o mínimo para sobreviver, todos os miseráveis que vivem pelas ruas, embora vivam na ignorância de Deus e de sua justiça, seriam mais abençoados e mais religiosos, os únicos candidatos para a vida eterna simplesmente porque não têm dinheiro...

Os primeiros Padres da Igreja culminam no grande Santo Agostinho (354-430) que, vivendo na época do saque de Roma em 410 e da ruína do Império Romano, teve de olhar adiante, para um mundo além da antiguidade, o qual muito iria influenciar. Nascido na Numídia, na África, Aurelius Augustinus foi educado em Cartago, e se tornou professor de retórica em Milão. Batizado como cristão aos 32 anos de idade, Santo Agostinho tornou-se bispo de Hipona, na sua região de origem, no Norte da África. O Império Romano sob Constantino abraçara o cristianismo um século antes, e Agostinho escreveu sua obra magna, A Cidade de Deus, como uma refutação à acusação de que a adoção do cristianismo resultara na queda de Roma.

Os pontos de vista econômicos de Agostinho estão espalhados pela $A$ Cidade de Deus e por outros de seus escritos altamente influentes. De uma vez por todas, e é provável, não independente de Aristóteles, chegou à conclusão de que aquilo que as pessoas pagam pelos bens, a valorização que lhes conferem, era determinada pelas próprias necessidades e não por qualquer critério objetivo ou pela posição que ocupam na ordem da natureza. Essa 
foi, no mínimo, a base para, posteriormente, a teoria austríaca de valor subjetivo. Também ressaltou que era desejo comum de todos os homens comprar barato e vender caro.

Além disso, Agostinho foi o primeiro Padre da Igreja a ter uma postura positiva para com o papel do mercador. Ao refutar as acusações patrísticas, comuns contra os mercadores, Agostinho mostrou que realizam um serviço benéfico ao transportar bens por grandes distâncias e vendê-los ao consumidor. Já que segundo o princípio cristão "o operário é digno de seu salário" ${ }^{\prime}$, então o mercador também merecia compensação pelas atividades e por seu trabalho.

À acusação comum de dolo e fraude endêmicos das atividades mercantis, Agostinho respondeu, de maneira convincente, que quaisquer mentiras e perjúrios, como aqueles, eram falta não do comércio, mas do próprio comerciante. Tais pecados eram gerados pela iniquidade da pessoa, não pela ocupação. Afinal, Agostinho assinalou, sapateiros e fazendeiros também são capazes de mentir e perjurar, e mesmo assim, os Padres da Igreja não condenaram tais ocupações como más em si mesmas.

Tirar dos mercadores a mácula de mal inerente provou ser de enorme influência nos séculos seguintes, e foi citada por diversas vezes na evolução do pensamento cristão nos séculos XII e XIII.

Uma colaboração menos tangível, mas que também ofereceu uma contribuição social importante foi a reforma da antiga visão de mundo de personalidade humana. Para os filósofos gregos, a personalidade individual deveria ser moldada conforme as necessidades e desejos da pólis. Ser preceito da pólis necessariamente significava uma sociedade estática, um desencorajamento de direito para quaisquer empresários inovadores que quisessem quebrar o molde da época. A ênfase de Santo Agostinho, no entanto, foi na personalidade individual que se manifesta $\mathrm{e}$, portanto, progride no tempo. Por isso a ênfase profunda de Agostinho no indivíduo, no

\footnotetext{
${ }^{9} 1 \mathrm{Tm}$ 5,18 e Lc 10,7. (N. do T.)
}

mínimo, preparou o campo, indiretamente, para uma postura favorável à inovação, ao crescimento econômico e ao desenvolvimento. Esse aspecto do pensamento agostiniano, por exemplo, não foi verdadeiramente reforçado pelos teólogos e filósofos do século XIII que construíram suas teses sob o pensamento de Agostinho. É irônico que o homem que preparou as bases para o otimismo e para a teoria do progresso humano devesse, no leito de morte, encontrar hordas de bárbaros sitiando sua amada cidade de Hipona.

Se Santo Agostinho olhou benignamente para a função do mercador, também favoreceu, embora não tão calorosamente, o papel social dos governantes dos Estados. De um lado, Agostinho tomou e expandiu a parábola de Marco Túlio Cícero (106-43 a.C.) que demonstrava que Alexandre, o Grande (356-323 a.C.) era simplesmente um pirata em larga escala, e que o Estado nada mais é que um bando de ladrões insitutídos. Na famosa obra A Cidade de Deus, Agostinho pergunta:

Desterrada a justiça, que é todo reino, senão grande pirataria? E a pirataria que é, senão pequeno reino? Também é punhado de homens, rege-se pelo poderio de príncipe, liga-se por meio de pacto de sociedade, reparte a mesa de acordo com certas conveniências. Se esse mal cresce, porque se lhes acrescentam homens perdidos, que se assenhoreiam de lugares, estabelecem esconderijos, ocupam cidades, subjugam povos, toma o nome mais autêntico de reino. Esse nome dá-lhes abertamente, não a perdida cobiça, mas a impunidade acrescentada. Em tom de brincadeira, porém a sério, certo pirata preso respondeu a Alexandre Magno, que lhe perguntou o que lhe parecia o sobressalto em que mantinha o mar. Com arrogante liberdade, respondeu-lhe: "O mesmo que te parece o manteres perturbada a Terra toda, com a diferença apenas de que a mim, por fazê-lo com navio de pequeno porte, me chamam de ladrão e a ti, que fazes com enorme esquadra, imperador" ${ }^{\prime \prime 1}$.

${ }^{10}$ A GOSTINHO, Santo. A Cidade de Deus. Trad. Oscar Paes Leme. Petrópolis: Vozes, 2002. Parte I, Livro IV, cap. IV, p. 153. (N. do T.) 
Agostinho, no entanto, finda por aprovar o papel do Estado, mesmo sendo um bando de ladrões em grande escala. Ao dar ênfase no indivíduo e não na pólis, à moda pré-calvinista, Agostinho ressaltou a maldade e a depravação do homem. Nesse mundo decaído, mau e pecador, o Estado governa, ainda que desagradável e coercitivo, e se torna necessário. Por isso Agostinho apoiou o aniquilamento compulsório da heresia donatista pela Igreja cristã no Norte da África, que acreditava, diferentemente de Agostinho, que todos os reis eram um mal necessário.

A comparação do chefe de Estado com um bandido em grande escala, no entanto, foi resgatada no original contexto antiestatal pelo grande papa Gregório VII, ao longo da luta contra os reis da Europa a respeito das reformas gregorianas no final do século XI. Essa força de antiestatismo pungente, então, emerge de tempos em tempos na primeira era cristã e na Idade Média.

\section{III - Os Carolíngios e o Direito CANÔNICO}

O direito canônico é a lei que rege a Igreja e, durante o período do cristianismo primitivo e a Idade Média, o entrelaçamento de Igreja e Estado muitas vezes indicava que o direito canônico e o direito estatal eram o mesmo. O primeiro direito canônico consistia em decretos papais, decretos dos concílios da Igreja e os escritos dos Padres da Igreja. Vimos que o direito canônico posterior também incorporou muito do direito romano, mas o direito canônico também incluía algo mais que era basicamente pernicioso: os decretos e regulamentos (capitulares) do Império Carolíngio nos séculos VIII e IX.

Dos séculos $\mathrm{V}$ ao $\mathrm{X}$, o caos político e econômico da Idade Média predominou em toda a Europa, e houve, consequentemente, pouco ou nenhum espaço para a evolução do pensamento político, jurídico ou econômico. A única exceção eram as atividades do Império Carolíngio, que floresceu na Europa Ociden- tal. O imperador carolíngio mais importante foi Carlos Magno (742-814) e sua regra recaiu nos sucessores durante o restante do século IX. Em capitulares e mais capitulares, Carlos Magno e seus sucessores estabeleceram regulamentações detalhadas para cada aspecto da vida econômica, política e religiosa por todo o Império. Muitos desses regulamentos foram incorporados no direito canônico nos séculos posteriores, permanecendo influentes bem depois do desmoronamento do próprio Império Carolíngio.

Carlos Magno erigiu sua despótica rede de regulamentações em bases inseguras. Assim, o importante Concílio de Niceia (325) proibira qualquer clérigo engajar-se em atividades econômicas que visassem o "lucro torpe" (turpe lucrum). Na assembleia de Nimègue (806) Carlos Magno reviveu, ampliou enormemente e impôs a antiga doutrina do turpe lucrum. Nessa ocasião, a proibição fora estendida do clero para todas as pessoas, e a definição foi ampliada, indo da fraude a toda a ganância e avareza, e incluía qualquer desobediência às extensas regulamentações de preço de Carlos Magno. Quaisquer desvios mercadológicos daqueles preços fixos lhes valia a acusação de estarem lucrando tanto com os vendedores quanto com os compradores e, portanto, era turpem lucrum. Como corolário, toda compra e venda especulativa de alimentos foi proibida. Além disso, prenunciou o direito consuetudinário inglês, ao proibir qualquer "açambarcamento"11, quaisquer comercialização de bens no exterior e a preços mais elevados que os regularmente praticados no mercado. Uma vez que o direito inglês era motivado não por uma tentativa mal orientada de auxílio aos pobres, mas por conferir privilégios monopolistas aos proprietários de

\footnotetext{
11 Prática comercial ilícita que se baseia na retenção de produtos e/ou matérias-primas com o intuito de uma elevação de preços ou enfraquecimento da concorrência. Ver: FERREIRA, Sérgio Carlos. Os Preços em Portugal na Baixa Idade Média: Metodologias, Políticas e Práticas. Disponível em <http://web.letras. up.pt/aphes29/data/5th/SergioCarlosFerreira_Texto. pdf $>$, p. 11. (N. do T.)
} 
comércios locais, é altamente provável que Carlos Magno também estivesse tentando cartelizar os mercados e conferir privilégios aos comerciantes locais.

Todo decreto de preço arbitrário do funcionalismo carolíngio era acatado pelos carolíngios como o "preço justo". Provavelmente, esse preço forçado, muitas vezes, estava próximo daquilo que fora o preço de costume ou o preço corrente nos arredores; caso contrário, seria difícil conceber como os funcionários públicos carolíngios descobriam qual preço seria considerado justo. Isso significava, contudo, uma tentativa, vã e não econômica, de congelar todos os preços tendo por base algum status quo mercadológico antigo.

O problema, portanto, é que o direito canônico posterior incorporou a ideia do justo preço como sendo o preço decretado pelo Estado. $\mathrm{O}$ banimento de qualquer preço maior que o preço de mercado corrente foi novamente fixado pelo finado imperador carolíngio Carlomano II (867-884) em 884 $4^{12}$, e incorporado na compilação de direito canônico de Regino de Prüm (†915), no ano 900, e mais de um século depois na compilação de Burchard de Worms (965-1025).

É possível notar duas tendências legais contraditórias: o tema do laissez-faire do Código de Teodósio e o motif estatista carolíngio. Ambas partem da grande compilação, base da disciplina medieval do direito canônico, a compilação de Santo Ivo de Chartres (10401116), na virada do século XII. Nessa mesma coletânea, encontramos o ponto de vista do justo preço como qualquer preço voluntariamente estipulado entre o comprador e o vendedor $e$ também encontramos o ponto de vista contraditório de que o justo preço é aquele decretado pelo Estado, especialmente se for o preço habitual dos mercados em geral.

\footnotetext{
12 Para um breve histórico da regulação dos preços no Império Carolíngio e seus desdobramentos nas leis canônicas, ver: LANGHOLM, Odd. The Legacy of Scholasticism in Economic Thought: Antecedents of Choice and Power. Cambridge University Press, 1998. p. 91-92. (N. do T.)
}

\section{IV - Os Canonistas e Romanistas} DA UNIVERSIDADE DE BOLONHA

A Alta Idade Média foi instituída pela revolução comercial dos séculos XI a XIII, nos quais o comércio, a produção e as finanças prosperaram, os padrões de vida elevaram-se perceptivelmente e as insitituições do capitalismo comercial se desenvolveram na Europa Ocidental. Com o advento do crescimento econômico e da prosperidade, os direitos canônico e romano, o pensamento social e o conhecimento também começaram a prosperar de novo.

A fonte e o grande centro dos estudos tanto do direito canônico quanto do direito romano na Alta Idade Média foi a Universidade de Bolonha, na Itália, cujo esplendor vai do início do século XII à última parte do século XIII. Durante esses dois séculos, tanto um quanto o outro direito, até mesmo o Código de Justiniano, foram redespertados em Bolonha, influenciaram-se mutuamente e penetraram no restante da Europa.

A grande e definitiva compilação de direito canônico, o Decretum Gratiani, foi publicada, por volta do ano 1140, pelo monge italiano Johannes Gratianus (ou Graciano), que fundou a cátedra de direito canônico na Universidade de Bolonha. O Decretum foi a obra definitiva de direito canônico dali em diante e, pelo restante do século XII, os estudiosos bolonheses, conhecidos como decretistas, elaboraram, debateram e glosaram a obra de Graciano.

O próprio Graciano e seus primeiros glosadores adotaram a fervorosa posição contra o mercado. A especulação, o comprar barato para vender caro - as atividades puramente mercantis - eram turpe lucrum e, inevitavelmente, envolviam fraude.

$\mathrm{O}$ primeiro decretista que começou a ter um posicionamento inteligente sobre as atividades comerciais foi Rufino, um professor de Bolonha que, posteriormente, veio a ser bispo de Assis e, depois, arcebispo de 
Sorrento. ${ }^{13} \mathrm{Na}$ sua Summa ${ }^{14}$ (1157-59) do Decretum, Rufino assinala que artesãos e artífices poderiam comprar materiais mais baratos, trabalhá-los e transformá-los e depois vender o produto a um preço mais elevado. Essa forma de comprar barato e vender caro era justificada pelas despesas e trabalho do artesão e era permitida tanto ao clero como aos leigos. Outra atividade, no entanto, praticada pelo simples mercador ou especulador, que compra barato e vende mais caro sem transformar o produto é, segundo Rufino, absolutamente proibida ao clero. $\mathrm{O}$ mercador leigo, contudo, pode ingressar honestamente nessas transações desde que tenha feito grandes despesas ou esteja cansado do trabalho árduo. A simples compra barata como empreendimento a ser seguida por uma venda quando os preços de mercado estiverem mais elevados foi incondiconalmente condenada por Rufino.

Tal reabilitação parcial do mercador pelos decretistas foi incluída na importante Summa ${ }^{15}$ de 1188 de Huguccio ou Hugo de Pisa (†1210), professor de Bolonha e, posteriormente, eleito bispo de Ferrara. Huguccio repetiu os pontos de vista de Rufino, mas modificou a justificativa do mercador, de trabalho ou despesas para ações que possibilitem o sustento à família do mercador. A ênfase de Huguccio, dessa maneira, não estava no custo objetivo, mas nas intenções subjetivas do mercador, supondo que pudessem ser descobertas: era simples ganância ou um desejo de

\footnotetext{
${ }^{13}$ Atualmente, há quem diga que Rufino de Sorrento e o Rufino canonista não sejam a mesma pessoa. Ver: The New Cambridge Medieval History: c. 1024-c.1198 part I. Ed. David Luscombe e Jonathan Riley-Smith. Cambridge: Cambridge University Press, 2004. p. 225, n. 85. (N. do T.)

${ }^{14}$ A obra foi impressa na seguinte edição contemporânea: RUFINUS VON BOLOGNA. Summa Decretorum. Ed. Heinrich Singer. Darmstadt / Paderborn: Scientia Verlag Aalen / Verlag Ferdinand Schöningh, 1963. (N. do T.)

${ }^{15}$ Recentemente a obra foi reeditada como: HUGUCCIO PISANUS. Summa Decretorum - Distinctiones I-XX. Ed. Oldrich Prerovský. Città del Vaticano: Biblioteca Apostolica Vaticana, 2006. (N. do T.)
}

prover as necessidades da família? Com certeza, Huguccio concedeu um espaço considerável para as atividades mercantis.

Ademais, Huguccio deu início a uma reconstrução radical dos ensinamentos patrísticos acerca da propriedade privada. A partir da época de Huguccio, a propriedade privada foi considerada um direito sacrossanto derivado da lei natural. A propriedade de indivíduos e comunidades era, no mínimo, em princípio, supostamente livre da invasão arbitrária por parte do Estado. Como "moderador e árbitro" dos próprios bens, um proprietário individual podia usar e dispor dos bens como lhe aprouvesse, dado que não violasse as regras legais gerais. Um governante só poderia expropriar a propriedade de um súdito inocente se a "necessidade pública" requeresse. Isso, é claro, era todo um sistema de direitos, visto que a "necessidade pública" podia ser e era um conceito elástico. Tal conceito de propriedade privada, todavia, era um avanço enorme nos ensinamentos patrísticos.

Depois do século XII, o movimento dos decretistas no direito canônico deu lugar aos decretalistas, ${ }^{16}$ que se baseavam numa torrente de éditos papais ou decretais, do final do século XII ao século XIII. Visto que o papa é supremo na Igreja Católica, as decretais proclamadas por ele ou pela curia vaticana eram automaticamente incorporadas no corpo do direito canônico. Dessa maneira, o direito canônico veio a diferir do de Graciano e dos decretistas, que erigiram a lei com base, principalmente, em antigas fontes. As novas decretais raramente eram arbitrárias; eram fundadas e elaboradas no direito canônico anterior. A continuidade desse processo de fundamentação foi amparada, em grande parte, pelo fato de vários dos papas serem bolonheses. Assim,

\footnotetext{
${ }^{16}$ A diferença entre os dois grupos era quanto aos métodos de ensino. Os decretistas eram aqueles que tomavam o Decreto de Graciano como a base dos trabalhos, realizando de glosas e sumas; e os decretalistas, eram os que dedicavam a comentar as Decretais de Gregório IX. Ver: GILISSEN, John. Introdução Histórica ao Direito. Lisboa: Fundação Calouste Gulbenkian, 2003. p. 149-150. (N. do T.)
} 
o papa Alexandre III (1100-1181), nascido Rolando Bandinelli, foi quem iniciou o novo processo de decretais num longo papado de 1159 a 1181. Ele estudara Direito e Teologia em Bolonha e, provavelmente, foi professor da Universidade, tendo tido contato direto com o grande Graciano. Como renomado jurista - escrevera ele mesmo uma Summa ao Decretum de Graciano - Rolando se tornou cardeal e chanceler da Universidade antes de ser eleito papa. Outro importante papa decretalista foi Inocêncio III (1160-1216), que governou a Igreja de 1198 a 1216; nascido Lotário de Segni, estudara direito canônico com Huguccio em Bolonha. Por fim, o papa Gregório IX (1160-1241), nascido Ugolino de Segni, exerceu o pontificado de 1227 a 1241, autorizou e publicou as importantes Decretais em 1234, incorporando o Decretum de Graciano do século anterior além de várias decretais papais. As Decretais de Gregório IX tornaram-se obra padrão do direito canônico daí em diante.

Os decretalistas tinham uma postura muito mais favorável que os primeiros decretistas para com os comerciantes e o livre mercado. Primeiramente, em vez da postura patrística negativa com relação aos mercadores e ao comércio, os decretalistas, a começar pelo papa Alexandre III até Gregório IX, incorporaram a posição de livre mercado do direito romano. Infelizmente não era a postura de puro laissez-faire de Teodósio ou mesmo do Código de Justiniano. Quando o Código de Justiniano chegou à Bolonha e à Europa Ocidental no início do século XII, o autor francês do Brachylogus Iuris Civilis fez uso do princípio da laesio enormis do Código de Justiniano e mudou significativamente o sentido. Em vez de aplicar o conceito de "preço justo" diferindo do preço real na avaliação dos danos, como no Código de Justiniano, o Brachylogus expandiu o conceito dos bens imóveis para todos os bens, e para a avaliação de danos nas vendas. Segundo o Brachylogus, se qualquer venda, até a voluntária, for feita por menos da metade do "preço justo", o vendedor pode apresentar a seguinte opção ao comprador: pagar a diferença entre o preço de venda e o preço justo, ou rescindir o contrato, com o comprador retornando os bens e o vendedor retornando o pagamento. Há que se notar que esse não é um mecanismo de cartelização, já que nenhuma das partes, nem o Estado, podem interferir para obrigar a laesio enormis; a execução da lei tem de partir da acusação formal feita pelo próprio vendedor.

O direito romano desenvolvido durante os séculos XII e XIII foi, em grande parte, produto da Universidade de Bolonha, onde os estudos de direito romano foram iniciados por Irnerius (1050-1125) no final do século XI. Em meados do século XII, os juristas romanos bolonheses começaram a incorporar o conceito mais amplo de laesio enormis do Brachylogus. Por volta de 1150, o provençal Lo Codi, a adaptação popular de uma recente Summa bolonhesa, acrescentou outra expansão fatal da laesio enormis. Pela primeira vez, essa obra provençal incluiu os compradores, bem como os vendedores, como sujeitos a experimentar laesio enormis, quando o preço de venda estivesse significativamente mais elevado que o preço justo. No Lo Codi, se um comprador tinha pagado mais do dobro do verdadeiro valor, ou preço justo, em um produto, então o vendedor tinha a opção de devolver ao comprador a diferença entre o preço de venda e o preço justo ou de rescindir o contrato. Extraordinariamente, quando o Lo Codi foi traduzido para o latim, essa nova restrição adicional ao laissez-faire foi acrescentada ao direito romano, pessoalmente por Alberico, professor de direito romano em Bolonha, na sua compilação de direito romano do final do século XII.

O florescente princípio da laesio enormis chegou ao máximo de sua expansão no final do século XII com a obra de Petrus Placentinus (1130-1192), treinado na Universidade de Bolonha. Placentinus diminuiu o preço máximo admissível para uma vez e meia do preço justo e além disso começaria a agir o princípio da laesio enormis. Esse desenvolvimento final foi incorporado nas obras de três grandes professores bolonheses de direito romano do século XIII: Azo de Lambertaciis (1210-1289); no influente aluno e discípulo de Azo, o flo- 
rentino Accursius (1182-1263); e culminou na escola bolonhesa de Odofredus (†1265), em meados do século XIII.

Embora seja verdade que os romanistas dos séculos XII e XIII tenham tomado o conceito trivial de laesio enormis e criado uma restrição significativa na liberdade de negociação e no laissez-faire, pelo menos, ao final do século XII, também deixaram claro que tinha de existir plena liberdade de negociação e a liberdade de enganar aos outros na matriz da laesio enormis. Os decretalistas, a começar pelo papa Alexandre III, incorporaram muito dessa evolução do direito romano. Isso significava que o direito eclesiástico agora incluía não só as fulminações patrísticas contra os negociantes per se, mas também contrastava a tradição romanista de plena liberdade de negociação com a matriz da laesio enormis. Os decretalistas chegaram ao auge, após tomar por base e glosar as Decretais de Gregório IX, nas obras do cardeal Henrico de Segusio, dito Hostiensis (1200-1271), primeiro em 1250 e, por fim, em 1271, o ano de sua morte. Hostiensis estudara direito canônico e romano em Bolonha, lecionara na Inglaterra e na França e era cardeal-arcebispo de Óstia.

Os decretalistas justificavam a compra e venda especulativa, liberando-a do pecado do turpe lucrum, ao adotar e expandindo a citação hugucciana de que a especulação seria permitida se o especulador estivesse agindo para suprir as necessidades da própria família. Na Glosa do canonista dominicano francês Guillaume de Rennes (†1250), essa área de liberdade foi ainda mais ampliada. As ações de um negociante ou especulador não eram consideradas pecaminosas até que ele fosse guiado por um "desejo lascivo por riquezas temporais, não para uso necessário ou utilidade, mas por curiosidade, de modo que a imaginação é atraída por tais coisas, assim como um pombo ou um corvo é seduzido por moedas que descobrem e escondem". Certamente esse tipo de restrição, que só se aplica a poucas pessoas no mundo real, vem de muito longe, desde as denúncias patrísticas dos mercadores e comerciantes per se.
Outra redução das restrições veio de Alanus Anglicus ${ }^{17}$, canonista inglês que lecionou em Bolonha e escreveu nas duas primeiras décadas do século XIII. Alanus declarou que o turpe lucrum (ou usura, nesse caso) poderia existir se o futuro preço de um bem fosse incerto na mente do mercador. Não só a incerteza está sempre presente no mercado, como também é impossível para tribunais e autoridades provarem que o comerciante não sentiu incerteza no momento em que comprou ou vendeu. De fato, todas as restrições ao turpem lucrum no comércio e na especulação, nesse momento, foram retiradas.

Ao analisar os lucros do comércio, os canonistas do final do século XIII acresceram à antiga justificativa de lucro como algo para cobrir o trabalho e as despesas. Era o elemento de risco, presente em todas as situações comerciais. O aumento do preço como consequência do risco foi justificado primeiramente nos famosos comentários de direito canônico do papa Inocêncio IV, nascido Sinibaldo Fieschi (1195-1254), publicados entre 1246 e 1253 . Antes de se tornar papa, Sinibaldo, natural de Gênova, fora estudar direito romano e canônico em Bolonha, tornou-se professor de direito romano nessa universidade e, por fim, cardeal e estadista famoso.

Se as transações deveriam ser pecaminosas e ilegais além de uma determinada faixa acima ou abaixo do preço justo, então a Igreja e as autoridades tinham de encontrar alguma maneira de resolver o que deveria ser o preço justo. Isso não fora um problema antes dos séculos XII e XIII, visto que a doutrina da laesio enormis realmente, até então, nunca havia sido posta em prática. A solução romanista e canônica, reminiscente da doutrina carolíngia, era

\footnotetext{
17 Alanus Anglius lecionou em Bolonha por volta dos anos 1190-1215. Compôs um influente apparatus do Decretum, denominado Ius Naturalis; compilou as decretais de Inocêncio III, bem como as decretais anteriores a esse papa conhecida como Collectio Alani; compôs um Apparatus sobre a Compilatio I (após 1207) e glosas sobre a Compilatio II. Sua coleção de decretais (e glosas) se tornou uma das fontes primárias da Compilatio Secunda (1210-12) de Johannes Galensis ou John de Wales (†1285). (N. do T.)
} 
a de que o preço justo seria preço de mercado habitual, atual, corrente (a communis aestimatio). Isso correspondia dizer tanto o preço geral de mercado, competitivo, em comparação a transações isoladas e únicas, ou poderia referir-se aos preços fixados pelos governos ou pelas guildas favorecidas pelo governo, uma vez que tais controles, pela legalidade estrita, poderiam ser o preço atual de iure. Talvez estivesse aquém da dignidade de tais juristas sancionar ou mesmo reconhecer quaisquer preços do mercado negro que violassem tais regulamentações.

Placentinus utilizou esse critério na jurisprudência romana no final do século XII, assim como o fez Azo, pormenorizadamente, no início do século XIII. Azo era liberal o bastante para referir-se ao preço como uma venda, que se iguala a qualquer outra que seja comparável como um "preço justo", mas Accursius, e depois dele Odofredus, referiram-se explicitamente ao preço de mercado habitual e geral como um padrão de justiça. Como Accursius expôs: "uma coisa era valorada por aquilo que seria usualmente vendida".

Os jurisconsultos canônicos adotaram o mesmo critério para o preço justo. Influenciado pela prática carolíngia e pelas sugestões do século VI da Regra de São Bento, o canonista Simão de Bisignano, do início do século XII e aluno de Graciano, descreveu pela primeira vez o verdadeiro valor dos bens como o preço pelo qual são usualmente vendidos. Canonistas e romanistas concordam, nesse momento, sobre o preço habitual como aquele que é bom e justo.

Os canonistas mais progressistas do século XIII, no entanto, ainda tinham um problema. De um lado, adotaram o ponto de vista da lei romana de que toda a livre negociação era legítima, salvo por uma faixa além ou aquém do "preço justo", que tomavam como o preço atual e habitual do mercado. Por outro lado, tinham herdado dos Pais da Igreja e dos primeiros decretistas uma hostilidade para com as transações mercantis, especialmente as especulativas. Como poderiam regularizar essa contradição?

Em parte, como já vimos, foram capazes de enfraquecer o alcance da vergonhosa especulação. Igualmente, do século XIII em diante, a Igreja e os juristas canônicos resolveram, em grande medida, o problema pela doutrina altamente sensata dos "dois foros de jurisdição" exercida pela Igreja. O "foro externo" - o jus fori - julgava as atividades sociais dos cristãos em tribunais eclesiásticos públicos. Essas cortes de justiça julgavam ofensas contra a Igreja e à lei comum com os mesmos procedimentos dos tribunais seculares. Por outro lado, o "foro interno" - o jus poli - era o confessional, em que o padre julgava os cristãos individualmente com base na relação pessoal com Deus. Os dois foros eram separados e distintos, os respectivos julgamentos se davam em dois níveis diferentes. Enquando a Igreja presumia governar ambos, o que era externo e social e o outro, privado e pessoal.

A doutrina dos dois foros permitiu aos canonistas resolver a aparente contradição do direito canônico. A livre negociação, a laesio enormis, o princípio mercadológico usual era o domínio da lei externa e do tribunal públi$\mathrm{co}$, onde, noutras palavras, um mercado livre poderia prosperar. Por outro lado, as restrições contrárias ao lucro mercantil iam além do trabalho, dos custos e dos riscos e eram uma questão, não de leis externas ou estatais, mas de leis confessionais e de consciência. Ainda mais óbvias que as determinações confessionais eram aquelas contrárias ao comércio e à especulação tendo por base a avareza, o que ia além da necessidade de sustento da família. Certamente, só o próprio homem, internamente, na sua consciência, poderia conhecer as próprias intenções; elas mal eram observáveis pela lei externa.

\section{V - A Proibição Canônica DA Usura}

O grande abrandamento de restrições legais e morais ao comércio que esteve presente nos canonistas e romanistas ao longo da Idade Média, infelizmente, não se aplica às severas proibições dirigidas à usura. As pessoas de hoje pensam em "usura" como taxas 
de juro muito elevadas cobradas sobre um empréstimo; mas esse não é, absolutamente, o verdadeiro sentido, essa interpretação é moderna. Em termos clássicos, "usura" significa qualquer índice cobrado por um empréstimo, sem importar o quanto seja. A proibição da usura era a proibição contra a cobrança de qualquer taxa de juro sobre o empréstimo.

Salvo um único povo, ninguém no mundo antigo - seja na Grécia, China, Índia ou Mesopotâmia - proibiu o juro. A exceção eram os judeus, que, numa expressão de moralidade tribal estrita, permitiram a cobrança de juros aos não judeus, mas proibiram-na entre judeus.

O feroz ataque medieval cristão à usura é, decididamente, estranho. Não há nada nos Evangelhos ou nos Padres da Igreja, não obstante a hostilidade que nutriam pelo comércio, que possa ser interpretado como uma incitação à proibição da usura. Na verdade, a parábola dos talentos (Mt 25,14-30) pode ser facilmente tomada como uma aprovação ao auferimento de juros em empréstimos comerciais. A campanha contra a usura começa no primeiro concílio da Igreja, em Niceia, no ano de 325 , ao proibir, unicamente aos clérigos, de cobrar juros nos empréstimos ${ }^{18}$. Tal concílio aferrou-se, no entanto, em um verso do Salmo 15 (14), no Antigo Testamento: "Iahweh, quem pode hospedar-se em tua tenda? [...][quem] não empresta dinheiro com usura". Esse verso tornar-se-ia o favorito, e praticamente o único, texto bíblico contra a usura durante a Idade Média. As prescrições de Niceia foram re-

\footnotetext{
${ }^{18}$ A regra encontra-se no cânon XVII que diz: "Clérigos usurários: Considerando que muitos clérigos, levados pela cobiça e fome vergonhosa de lucros, se esqueceram da divina Escritura que diz: 'não emprestou dinheiro a juros' (Sl.14, 5) exigem percentagens sobre seus empréstimos, o sagrado e magno Concílio decretou o seguinte: Quem depois deste decreto for encontrado na prática de receber juros ou coisa parecida, ou negociar à base de três por dois ou excogitar outras coisas deste gênero, em busca de lucro vergonhoso, será excluído do clero e ficará como que estranho à regra canônica". (Documentos dos Primeiros Oito Concílios Ecumênicos. Trad. Otto Skrzypczak, Intr. Urbano Zilles. Porto Alegre: EDIPUCRS, 2ª ed., 2000. p. 25). (N. do T.)
}

petidas em outros concílios no século quarto, como no Concílio de Elvira, na Hispânia ${ }^{19} \mathrm{e}$ em Cartago ${ }^{20}$. No século V, o papa Leão I, o Grande (400-461), também conhecido como Leão Magno, estendeu a proibição da prática também aos leigos, condenando os usurários leigos tomados pelo turpem lucrum ${ }^{21}$. Vários concílios locais na Gália no século VII repetiram a condenação de Leão Magno, assim como o fez o papa Adriano I (700-795) e vários sínodos da igreja inglesa no século VIII ${ }^{22}$.

${ }^{19}$ A data desse concílio regional é incerta e deve ter ocorrido entre os anos de 303 a 324 . A tradição atribui ao concílio 81 cânones. As regras de proibição do lucro e da usura podem vistas nos cânones 19 e 20. No caso da usura, o concílio estende a proibição aos leigos, como vemos no cânon XX: "Se algum clérigo for envolvido em usura, deixai que seja censurado e repudiado. Se um leigo for pego praticando a usura, pode ser perdoado caso prometa deixar de praticá-la. Se continuar nesta prática do mal, que seja expulso da Igreja". (N. do T.)

20 A Igreja de Cartago, no ano de 348, insiste na proibição de Niceia, mas elimina a penalidade. Admite, todavia, que a usura "é um pecado condenável até mesmo aos leigos" (Cânone XIII), e justifica a proibição tanto no Antigo como no Novo Testamento ao afirmar que "ninguém age contra os profetas nem contra os Evangelhos sem perigo". Ver: MANSI. Conciliorum. 2:9. (N. do T.)

${ }^{21}$ Sobre as condenações de Leão Magno à usura, ver Carta Ut Nobis Gratulationem, aos bispos da Campânia, Piceno e Túscia, de 10 de outubro de 443, que, no capítulo 3, afirma: "Julgamos também não dever preterir o fato de que alguns, tomados pelo desejo de lucro torpe, praticam negócios com juro e querem enriquecer-se com o rendimento; isto nos entristece, digo, não só quando acontece entre os constituídos num ministério clerical, mas também no caso de leigos que desejam ser chamados de cristãos. Determinamos que se exija severo castigo para os que forem encontrados culpados, para que seja eliminada qualquer ocasião de pecado". Ver: DENZINGER, H. Compêndio dos Símbolos, Definições e Declarações de Fé e Moral. Trad. José Marino e Johan Konings. São Paulo: Paulinas: Edições Loyola, 2007. p. 280. (N. do T.)

${ }^{22}$ Sobre as proibições da igreja inglesa, ver o Penitencial (uma espécie de código de penas para ofensas morais) de Egberto de York (†766) que influenciou enormente a Igreja inglesa. A mesma condenação pode ser vista na carta dos legados papais, Jorge I, bispo de Óstia e Teofilato, bispo de Todi, ao relatar ao papa Adriano I os procedimentos do concílio reunido em Chalchyth no ano de 787, em Cumberland, na Inglaterra. Afirmam ter proibido a usura e citam a autoridade do salmista 
A proibição plena da usura entra na legislação secular pela primeira vez no regime amplamente totalitário do imperador Carlos Magno (742-814). No fatídico sínodo imperial de Aachen, em 789, Carlos Magno proibiu a usura para todos no seu reino (omnino omnibus), fossem clérigos ou leigos ${ }^{23}$. A proibição foi renovada e elaborada em um concílio posterior em Nijmegen, no ano de 806, onde a usura foi definida pela primeira vez, como uma troca em que "é exigido mais em retorno do que aquilo que é dado" ${ }^{24}$. Dessa maneira, desde a época de Carlos Magno, a usura, com muita intensidade, foi tida como uma forma especial e particularmente malévola de turpe lucrum, e as tentativas de relaxar essa proibição sofreram uma feroz resistência. A definição ampla de ser "exigido mais em retorno do que aquilo que é dado", foi repetida sem alterações do canonista do século X, Regino de Prüm, passando por Santo Ivo de Chartres até Graciano.

Muito curiosamente, embora continuasse a hostilidade, imensamente reforça-

e de Santo Agostinho. Ver: Councils and Ecclesiastical Documents Relating to Great Britain and Ireland. Ed. Adam W. Haddan e William Stubbs. Oxford: Clarendon Press, 1871. vol. III, p. 457. Igualmente, os concílios de Mayence, Reims e Chalons, no ano 813, e o de Aix, no ano 816 , parecem repetir a mesma proibição tanto para os clérigos quanto para os leigos. Ver: HARDOUIN, Jean. Acta Conciliorum et Epistolae Decretales ac Constituitiones Summorum Pontificiorum. Paris: Ex. Typographia regia, 1715. vol. IV, p. 1011, 1020, 1033, 1100. (N. do T.)

${ }^{23}$ Nessa ocasião, o Imperador reportou-se ao Concílio de Niceia e ao papa Leão I. Ver: C. 5, Karoli Magni Capitularia, Admonitio Generalis. In: Capitularia. Ed. M. G. H., Boretius, 1: 54. (N. do T.)

24 C.11, Karoli Magni Capitularia, Capitulare Missorum Niumagae datum, ibidem, 1: 132. Segundo John W. Baldwin, é provavel que tal definição capitular se referisse "tão somente aos contratos de empréstimo (mutuum), no entanto, a terminologia utilizada foi bastante ampla para gerar dúvida moral, por analogia, quanto aos lucros derivados de outros contratos". Sobre essa questão, ver: BALDWIN, John W. The Medieval Theories of Just Price: Romanists, Canonists and Theologians in the Twelfth and Thirteenth Centuries. Transactions of the American Philosophical Society, vol. 49, parte 4, Philadelphia: American Philosophical Society, 1959. p. 32. (N. do T.) da entre canonistas, com a usura, o princípio básico explícito do antagonismo mudou de modo considerável. Ao longo dos primeiros séculos da era cristã, a usura era infame por ser uma forma de avareza ou de falta de caridade; ainda não era considerada um pecado vicioso contra a justiça. Como o comércio, no século XI, começou a reaparecer e a se desenvolver na Europa, de fato, denunciar o ganho de juros como uma forma de falta de caridade começou a ser considerado algo irrelevante, uma vez que a caridade tinha pouca relação com empréstimos comerciais. Foi o monge italiano Santo Anselmo da Cantuária (10331109) quem primeiro mudou a base do ataque, ao censurar severamente a usura como "furto". Essa nova doutrina foi desenvolvida por um discípulo de Santo Anselmo, Santo Anselmo de Lucca (1036-1086), outro italiano e nativo de uma cidade com uma florescente indústria têxtil (Milão). Na sua coletânea de cânones, realizada por volta de 1066, Anselmo de Lucca explicitamente condena a usura como furto e um pecado contra o sétimo mandamento, e exige a restituição do que foi dado como usura ao tomador do empréstimo como "bens furtados". Essa expansão do "furto" ao contrato voluntário em que não foi utilizada nenhuma coerção foi, certamente, estranha, e, no entanto, esse novo conceito exorbitante foi aceito e repetido por Hugo de São Vitor (10961141) e nas coletâneas de Ivo de Chartres.

Em 1139, o segundo Concílio de Latrão da Igreja explicitamente proibiu a usura a todos os homens, leigos e clérigos, e afirmou que todos os usurários eram infames. ${ }^{25} \mathrm{O}$ Concílio

\footnotetext{
${ }^{25}$ Ao contrário do afirmado por Rothbard, a proibição omnino omnibus não está presente no Segundo Concílio de Latrão, no entanto, há uma curiosa ressalva na relação do clero com usurários ("desde que o façam com extrema cautela"), o que demonstra uma tendência na Igreja de, por vezes, mitigar o rigor do interdito de Niceia, seja por não mencionar os leigos ou por admitir exceções ao clero. Diz o Concílio: "Cânon XIII: Além disso, condenamos a prática desprezível e censurável pelas leis divinas e humanas, denunciadas nas Escrituras, no Antigo e no Novo Testamento, ou seja, a feroz ganância dos usurários; e serão privados de todo o conforto da igreja, ficando vetado a qualquer bispo ou arcebispo, ou abade de
} 
menciona vagamente que o Antigo e o Novo Testamento ordenam tal proibição, mas não oferece nenhuma referência explícita. Nove anos depois, o papa Eugênio III (1100-1153) foi contra a prática comum dos monastérios de cobrar juros sobre hipotecas.

Finalmente, o direito canônico chega à maturidade com o Decretum de Graciano ${ }^{26}$. Graciano insiste na argumentação contra a usura com todas as armas possíveis, do Salmo 15 (14) até o novo ponto de vista de que a usura é furto e, portanto, exige restituição. Ao explanar a respeito da proibição estrita da usura, Graciano estende seu escopo aos empréstimos de bens e aos de moeda, de modo que qualquer coisa exigida além do principal - e expressamente o declara que, nesse caso, o "preço justo" não é o preço habitual de mercado, mas zero, ou seja, o equivalente exato dos bens ou dinheiro emprestados.

O grande decretalista, o papa Alexandre III (1100-1181), pode ter sido favorável ao livre mercado em outras áreas, mas com relação à usura, simplesmente aprofundou e ampliou a proibição, ao condenar a cobrança de preços mais altos nas vendas a crédito que nas vendas à vista. Tal prática foi denunciada como usura implícita, embora não fosse explicitamente juros sobre um empréstimo. O terceiro Concílio de Latrão, presidido pelo papa Alexandre III em 1179, condenou a usura, excomungando e negando a sepultura aos usurários notórios ${ }^{27}$. O papa seguinte, Urbano

qualquer ordem ou qualquer um em ordens clericais, ousar receber usurários, desde que o façam com extrema cautela; mas que sejam [os usurários] considerados infames por toda a vida e, a menos que se arrependam, sejam privados de um enterro cristão". (N. do T.)

${ }^{26}$ No Decretum de Graciano, a questão da usura é apresentada em duas seções gerais. A primeira e menos importante encontra-se no final da Distinctio XLVI e início da Distinctio XLVII e a outra seção, mais importante, está nas Questiones III e IV da Causa XIV. (N. do T.)

${ }^{27}$ Diz o cânon XXV do referido Concílio: "Por quase toda a parte o crime de usura se tornou tão enraizado que muitos, omitindo outros negócios, praticam usura como se fosse permitida, e de modo algum notam como é proibida, tanto no Antigo como Novo Testamento. Portanto, declaramos
III (1130-1187), na decretal Consoluit, desenterrou uma citação de Jesus nunca antes utilizada: "emprestai, sem daí esperar nada" (Lc $6,36)$, que desse momento em diante se tornou a peça central da condenação teológica da usura como pecado mortal; e não só isso: até a própria expectativa de obter usura equivalia, praticamente, a um pecado mortal.

A obssessão canônica com a usura foi tão universal que Graciano, seus predecessores e sucessores, em grande parte elaboraram as teorias a respeito de compra e venda, lucro ou preço justo em termos de se a referida transação recairia ou não na rubrica temível de "usurária". Assim, os decretistas do final do século XII como Simão de Bisignano em 1179, e o grande Huguccio em 1188, mantiveram a proibição estrita da cobrança de qualquer juro nos empréstimos, cobrança esta considerada usura, ao passo que não consideraram usura, $o$ aluguel de bens ou a compra de um bem a preço menor e venda a maior valor. A tormentosa distinção moral de Huguccio de que um commodatum - um contrato de cessão que transfere somente o uso de um bem - era, de certa maneira, muito diferente do contrato de mutuum - um empréstimo autêntico em que a propriedade era transferida por um determinado tempo. Cobrar por um arrendamento, um commodatum não gerava problemas porque o proprietário mantinha a propriedade e cobrava pelo uso de seu bem; mas, de alguma maneira isso se tornava pecaminoso quando o emprestador cobrava pelo uso de um bem que não possuia (temporariamente). Lucros sobre o comércio, também poderiam ser legítimos e legais como a recompensa por um risco, mas juros sobre um empréstimo - em que o risco surge para o tomador do empréstimo e não para o emprestador - sempre era tido como usura.

Os decretalistas posteriores, ao tentar combater a prática dos mercadores de disfar-

que usurários notórios não devem ser admitidos à comunhão do altar ou receber exéquias cristãs, caso morram nesse pecado. Quem recebe ou dá-lhes funeral cristão deve ser obrigado a devolver o que recebeu, e permanecer suspenso do desempenho do cargo, até que tenha feito penitência, segundo o juízo do próprio bispo". (N. do T.) 
çar a usura em vários contratos, apressaram-se em condenar tais contratos como "usura implícita", visto que, como vimos ao tratar dos contratos de compra e venda, não havia incerteza quanto ao preço futuro na mente do comprador e do vendedor. O canonista do início do século XII, Alanus Anglicus, declarou que se houvesse incerteza em tal contrato, e o comprador e o vendedor tivessem chances iguais de ganhar e perder, não existia a usura. Ao proporcionar a primeira brecha real, apesar de pequena, na proibição abrangente da prática da usura, Anglicus explicou que essa forma de usura implícita poderia existir somente no intelecto e não poderia estar sujeita à imposição jurídica. Essa brecha de incerteza foi ligeiramente ampliada nas Decretais de Gregório IX.

Por outro lado, os canonistas persistiram em reprimir as evasões da proibição da usura que o mercado insistia, criativamente, em inventar. Contratos que previam pagamentos diferidos numa venda eram tratados com suspeita, e preços muito altos em tais contratos eram tomados, pelos canonistas, como prova da intenção de cometer usura, sem sombra de dúvida. As Decretais também chegaram a ponto de condenar credores que cobravam juros de mercadores viajantes, muito embora os canonistas percebessem que os juros eram uma compensação direta pelos riscos. Apesar dos canonistas após Inocêncio IV começarem a falar de riscos para justificar lucros, de modo que o lucro em investimentos de risco era considerado perfeitamente justificável, qualquer juro num empréstimo autêntico (ou mutuum) era condenado como usura, não obstante as circunstâncias razoavelmente atenuantes.

A proibição da usura foi uma trágica imperfeição nos pontos de vista econômicos dos juristas e teólogos medievais. A proibição era economicamente irracional, privava os tomadores de empréstimo marginais e elevava os riscos de crédito de qualquer capital que pudesse ser emprestado. Não tinha base alguma no direito natural e praticamente nenhum fundamento nos ensinamentos do Antigo ou do Novo Testamento. E, ainda assim, esteve ferozmente arraigada por toda a Idade Média, de modo que os juristas e teólogos tinham de empreender engenhosas e astutas reviravoltas na argumentação para criar exceções à proibição e acomodar a prática crescente de empréstimo de dinheiro e a cobrança de juros sobre o empréstimo. Ainda, os medievalistas, especialmente, os filósofos e teólogos posteriores, salientavam um ponto fascinante e essencial: Qual era a justificativa moral e econômica do juro sobre o empréstimo autêntico? Como veremos, os escolásticos medievais vieram a compreender plenamente as justificativas morais e econômcias de quase todos os aspectos da cobrança de juros: como um lucro implícito sobre o risco, como uma oportunidade perdida de auferir lucro dos investimentos, e muitas outras. Por que existe, no entanto, a cobrança de juros em empréstimos simples, sem riscos e não derivados de oportunidades perdidas? A pergunta não foi plenamente respondida até o advento da escola austríaca no século XIX. A falta grave na percepção dos escolásticos não era se os juros eram pagos ou cobrados voluntariamente, o que, por si só, é justificativa moral suficiente; ia além disso, a falha era não perceber que deveria haver uma explicação econômica, muito embora a ciência econômica ainda não a tivesse descoberto.

A primeira violação sistemática da proibição de usura veio com o último dos canonistas do século XIII, o cardeal Hostiensis, Além de ter sido um notável professor de Direito, Hostiensis era um cosmopolita e conhecia o mundo. Fora embaixador de seu amigo, o papa Inocêncio IV na corte de Henrique III (1207-1272). Primeiro, Hostiensis voltou à antiga tradição mais branda da usura como falta de caridade, mas não um pecado contra a justiça. Depois, listou nada menos que 13 casos em que a proibição da usura poderia ser violada e os juros sobre um empréstimo poderiam ser cobrados. Um dos casos é a necessidade de garantia do avalista de um empréstimo; outro, a do vendedor poder cobrar um preço mais elevado pela mercadoria vendida a cré- 
dito e não a vista, dado que há incerteza (e, de fato, ela sempre existe) a respeito do preço futuro do bem. Outra exceção importante é a admissão do credor apor cláusula penal no empréstimo, de modo que o devedor tenha de pagar a penalidade sobre o principal, caso não efetue o pagamento da data devida. Isso, é claro, aplainou as veredas para poder haver um acordo velado entre as partes adiando o pagamento, de modo a permitir a "penalidade". Outra exceção era o credor poder cobrar pelo trabalho que empreendeu para realizar aquele empréstimo determinado.

Essas eram algumas formas de penalidade ou pagamento especial. Além disso, Hostiensis elaborou o primeiro e pioneiro argumento para a cobrança inicial de taxa de juros de um empréstimo, uma cobrança que não envolvia mora ou garantias. Eram o $l u$ crum cessans (lucro cessante), uma legítima cobrança de juros pelo credor para compensar o lucro perdido de um investimento para si mesmo. Em suma, o lucrum cessans antecipava o conceito austríaco de custo de oportuni- dade, de renda perdida, que fora aplicado à cobrança de juros. Infelizmente, contudo, o uso do lucrum cessans pelo cardeal Hostiensis estava limitado aos credores não habituais, que emprestam dinheiro por caridade ao devedor. Assim, credores não poderiam estar nesse comércio de cobrança de empréstimo, mesmo com base no lucrum cessans.

Outra exceção criada por Hostiensis também abria um canal para a cobrança de juros nos empréstimos. Permitia que o devedor fizesse uma doação gratuita ao credor, desde que a "oferenda" não fosse solicitada pelo credor. Nesse caso os devedores, em particular os banqueiros florentinos que recebiam depósitos, se sentiam obrigados a fazer "ofertas" aos depositários, caso contrário os depositários poderiam mover seus fundos e entregá-los para a concorrência que usualmente faziam tais "ofertas". A criação dessa "falsa oferenda" tornou-se um importante mecanismo que de facto permitiu a cobrança de juros.cos 